\title{
PERAN DOKTER DI TEMPAT KEJADIAN PERKARA DI KOTA MANADO
}

\author{
${ }^{1}$ Theo L. Siwu \\ ${ }^{2}$ Djemi Tomuka \\ ${ }^{2}$ Nola T. S. Mallo \\ ${ }^{1}$ Kandidat Skripsi Fakultas Kedokteran Universitas Sam Ratulangi Manado \\ ${ }^{2}$ Bagian Forensik Kedokteran Forensik \& Medikolegal Fakultas Kedokteran \\ Universitas Sam Ratulangi Manado \\ Email: s_theo@ymail.com
}

\begin{abstract}
In general, a doctor will face a variety of patients that needed to be treated. However, treating patients is not the only role of a doctor. Doctors can also be called to serve in court of justice, therefore, serving the law is one of the most important aspects of a good doctor. In Indonesia, especially in Manado, a lot of criminal cases leading to death can be found. Concerning death cases, the law enforcement have to consult the Forensic Department. The request might come in the form of an autopsy which is to figure out the cause of death or the identity of the victim. In certain places, it is common to use a forensic doctor as a specialist in crime scene area. This was a descriptive analytical study using questionairre as primary data. Conclusion: From all the data it can be concluded that a doctor's role in crime scene area is very important. Therefore, the investigator in crime scene area can handle the cases with medical related problem much beter.
\end{abstract}

Keywords: doctor's role, crime scene.

\begin{abstract}
Abstrak: Seorang dokter akan berhadapan dengan bermacam-macam pasien dalam kehidupannya tetapi menangani pasien bukan menjadi satu-satunya tugas seorang dokter. Dokter juga bisa dipanggil untuk menjadi seorang saksi ahli pada kasus-kasus dengan tindakan pidana. Peranan seorang dokter untuk membantu tindak keadilan merupakan salah satu aspek yang cukup penting. Di Indonesia khususnya di Manado telah cukup banyak kasus kejahatan yang berujung pada kematian. Dalam hal kasus kematian maka pihak kepolisian akan datang meminta bantuan ke pihak forensic antara lain dalam bentuk autopsi untuk meneliti sebab kematian dari mayat atau mencari tahu identitas korban. Di beberapa negara telah digunakan jasa seorang dokter forensik sebagai salah satu tenaga ahli di tempat kejadian perkara. Penelitian ini menggunakan metode deskriptif analitik dengan kuesioner sebagai data primer. Simpulan: Dari hasil yang didapatkan disimpulkan bahwa peran dokter di tempat kejadian perkara sangat penting. Dengan adanya bantuan dari pihak kedokteran maka para penyidik dapat menangani kasus-kasus yang berkaitan dengan medis secara lebih baik.
\end{abstract}

Kata kunci: peran dokter, tempat kejadian perkara.

Pekerjaan dokter forensik biasanya dimulai pada saat mayat dibawah ke ruang autopsi tetapi tidak menutup kemungkinan bilamana seorang dokter forensik ataupun seorang dokter umum untuk dipanggil dan memulai pekerjaanya di tempat kejadian perkara. Di beberapa tempat di dunia banyak yang telah menggunakan jasa seorang dokter forensik sebagai salah satu tenaga ahli di tempat kejadian perkara.

Di Indonesia khususnya di Manado, tenaga ahli dari pihak kedokteran sangatlah jarang ditemukan di tempat 
kejadian perkara. Di kota Manado sudah banyak terjadi pembunuhan dengan mengunakan senjata.tajam. Tentu saja dengan tenaga kedokteran forensik para pihak berwajib dapat mengetahui apa penyebab kematian pada korban, dan dengan mengetahui penyebab kematian maka pihak pneyidik dapat mengetahui senjata yang digunakan sang pelaku dan bukan tidak mungkin dengan semua bukti yang ada pihak penyidik dapat menangkap atau mengungkapkan pelaku sebenarnya, tapi proses penyelesaian semua langkah di atas membutuhkan waktu yang lebih lama. Dengan menggunakan jasa seorang dokter forensik di lapangan atau dalam hal ini tempat kejadian perkara, maka pihak penyidik dapat memperpendek waktu yang digunakan untuk menyelesaikan proses-proses tersebut dan dapat menghapus kemungkinan sang pelaku untuk lari dari dan bersembunyi dari hukum.

\section{ILMU KEDOKTERAN FORENSIK}

Berkenan dengan atau dilakukan dalam tindakan hukum ${ }^{1}$ Ilmu kedokteran forensik, juga dikenal dengan nama Legal Medicine, adalah salah satu cabang spesialistik dari ilmu kedokteran, yang mempelajari pemanfaatan ilmu kedokteran untuk kepentingan penegakan hukum serta keadilan. $^{2}$

Di masyarakat kerap terjadi peristiwa pelanggaran hukum yang menyangkut tubuh dan nyawa manusia. Untuk pengusutan dan penyidikan serta penyelesaian masalah hukum ini di tingkat lebih lanjut sampai akhirnya pemutusan perkara di pengadilan, diperlukan bantuan berbagai ahli di bidang terkait untuk membuat jelas jalannya peristiwa serta keterkaitan antara tindakan yang satu dengan yang lain dalam rangkaian peristiwa tersebut. Dalam hal terdapat korban, baik yang masih hidup maupun yang meninggal akibat peristiwa tersebut, diperlukan seorang ahli dalam bidang kedokteran untuk memberikan penjelasan bagi para pihak yang menangani kasus tersebut. Dokter diharapkan membantu dalam proses peradilan ini akan berbekal pengetahuan kedokteran yang dimilikinya yang terhimpun dalam kazanah Ilmu Kedokteran Forensik. ${ }^{2}$

Ilmu forensik (biasa disingkat forensik) adalah sebuah penerapan dari berbagai ilmu pengetahuan untuk menjawab pertanyaanpertanyaan yang penting untuk sebuah sistem hukum yang mana hal ini mungkin terkait dengan tindak pidana. Namun disamping keterkaitannya dengan sistem hukum, forensik umumnya lebih meliputi sesuatu atau metode-metode yang bersifat ilmiah (bersifat ilmu) dan juga aturanaturan yang dibentuk dari fakta-fakta berbagai kejadian, untuk melakukan pengenalan terhadap bukti-bukti fisik (contohnya mayat, bangkai, dan sebagainya). ${ }^{3}$

\section{DOKTER FORENSIK DI TKP}

Dokter mendapatkan posisi legal melalui surat dari lembaga hukum (Legal Institute yaitu Pengadilan, Kejaksaan, dan Polisi) yang meminta dokter untuk memeriksa seseorang yang telah mempunyai status hukum tertentu: terdakwa, saksi, penggugat, dan sebagainya. $^{4}$

Proses penegakan hukum dan keadilan merupakan suatu usaha ilmiah dan bukan sekedar common-sense, non-scientific belaka. Dengan demikian di dalam penyelesaian perkara pidana yang menyangkut tubuh, kesehatan dan nyawa manusia; seperti kasus pembunuhan, penganiayaan, kejahatan seksual, perbuatan yang menyebabkan kematian atau perlukaan, Ilmu kedokteran Forensik mutlak diperlukan. ${ }^{5}$

Baik ilmu kedokteran forensik, dalam penyidikan perkara tindak pidana yang menyangkut tubuh, kesehatan dan nyawa manusia dalam garis besarnya dapat dibagi menurut tahapan-tahapan sebagai berikut, yaitu; 6

- Pada pemeriksaan tempat kejadian perkara.

- Pada pemeriksaan korban, baik pemeriksaan terhadap korban yang telah 
menjadi mayat maupun pada pemeriksaan korban kejahatan seksual, penganiayaan dan lain sebagainya.

- Pada saat dilakukan rekonstruksi suatu kejahatan dan interograsi.

\section{PEMERIKSAAN DI TEMPAT KEJADIAN PERKARA}

Peranan penyidik dalam melakukan penanganan tempat kejadian perkara: ${ }^{7}$

a. Melakukan pengamanan tempat kejadian perkara tindak pidana dengan memasang police line (garis polisi) yang berfungsi melarang siapapun masuk kedalam police line kecuali penyidik.

b. Tim penyidik mencari dan menemukan barang bukti yang berada ditempat kejadian perkara serta mengumpulkan barang bukti sesuai dengan petunjuk teknis pengumpulan bukti yang berada di dalam tempat kejadian perkara.

c. Melakukan pemotretan pada tempat kejadian perkara terhadap barang bukti yang masih belum dipindahkan korban bila sudah mati sesuai dengan ketentuan teknis pemotretan di tempat kejadian perkara.

d. Meminta keterangan kepada orangorang yang melihat mendangar dan mengalami sendiri terjadinya peristiwa tindak pidana

e. Melakukan penangkapan tersangka bila terdapat di tempat kejadian perkara.

Agar proses penyidikan dapat berjalan lancar, maka penyidik dan dokter perlu mengetahui bagaimana cara penanganan yang seharusnya bila mereka melakukan pemeriksaan di tempat kejadian perkara kejahatan. $^{8}$

- Bilamana pihak penyidik mendapat laporan bahwa suatu tindak pidana yang menyangkut nyawa manusia (mati), telah terjadi maka pihak penyidik dapat minta bantuan dari dokter untuk nmelakukan pemeriksaan di tempat kejadian perkara tersebut (dasar hukum: Pasal 120 KUHAP; pasal 133 KUHAP).

- Bila dokter menolak datang ke tempat kejadian perkara, maka pasal 224 KUHP, dpat dikenakan kepadanya,
- Dokter tersebut harus selalu ingat untuk tidak melakukan tindakan-tindakan yang dpat merubah, mengganggu atau merusak keadaan di tempat kejadian tersebut; walaupun sebagai kelanjutan dari pemeriksaan itu dokter harus mengumpulkan segala benda bukti (trace evidence), yang ada kaitannya dengan manusia; air mani yang terdapat pada pakaian, sisa obat dan makanan, yang pada dasarnya tindakan tersebut akan merusak keadaan/keaslian tempat kejadian itu sendiri.

- Dengan demikian, sebelum dokter melakukan pemeriksaan maka tempat tersebut haruslah diamankan (dijaga keasliannya), oleh petugas, dan diabadikan dengan membuat foto atau sketsa keadaan di TKP, sebelum para petugas menyentuhnya.

- Sebelum dokter datang ke TKP, ada beberapa hal yang harus dicatat mengingat akan kepentingannya yaitu:

1. Siapa yang meminta datan ke TKP (otoritas), bagaimana permintaan tersebut sampai ke tangan dokter, dimana TKP, serta saat permintaan tersebut diajukan.

2. Minta informasi secara global tentang kasusnya, dengan demikian dokter dapt membuat persiapan seperlunya.

3. Perlu diingat motto: "to touch as little as possible and to displace nothing”; ia tidak boleh menambah atau mengurangi barang-barang yang ada di TKP, dokter tidak boleh sembarangan membuang puntung rokok, perlengkapan jangan sampai tertinggal, jangan membuang air kecil di kamar mandi/wc, karena dengan melakukan hal tersebut benda-benda bukti dapat hanyut dan hilang terbawa air.

4. Di TKP dokter membuat foto dan sketsa yang mana harus disimpan dengan baik, oleh karena ada kemungkinan ia akan diajukan sebagai saksi di pengadilan selalu ada, foto dan sketsa yang dubuat tersebut berguna untuk lebih mudah 
bagi dokter untuk mengingat kembali akan kasus yang diperiksanya.

5. Pembuatan foto atau sketsa harus memenuhi standar sehingga kedua belah pihak yaitu dokter dan penyidik tadak akan memberikan penafsiran yang berbeda atas objek yang sama

6. Sebagai gambaran umum dalam hal penilaian dari situasi di TKP, ailah: bila keadaan tempat atau ruangan itu tenang dan teratur rapih, maka dapat dipikirkan bahwa kemungkinan kasus yang dihadapi adalah kasus bunuh diri atau kasus kematian mendadak akibat penyakit non traumatik, dan bila keadaan pada ruangan tersebut tidak beraturan, kacau balau, banyak terdapat bercak darah, maka dapat dipikirkan akan kemungkinan bahwa ditempat tersebut telah terjadi perkelahian, sehingga kasusnya menjurus ke penganiayaan atau pembunuhan.

7. Pemeriksaan atas tubuh korban hendaknya dilakukan secara sistematik berdasarkan ilmu kedokteran forensik yang terarah sesuai dengan perkiraan kasus yang dihadapi.

\section{PROSEDUR PEMERIKSAAN DI TKP}

Pemeriksaan dokter di TKP atas diri korban bertujuan untuk mendapatkan data yang akurat dalam tempo singkat dan melakukan beberapa test lapangan, yang berguna bagi pihak penyidik agar ia dapat menentukan strategi serta langkah yang tepat untuk dapat membuat jelas dan terang suatu perkara pidana yang menyangkut tubuh manusia.

Tindakan yang dapat dikerjakan oleh dokter ialah: ${ }^{6}$

1. Menentukan apakah korban masih hidup atau telah tewas, bila masih hidup, upaya terutama ditujukan untuk menolong jiwanya; hal yang berkaitan dengan kejahata, dapat ditunda untuk sementara.
2. Bila korban telah tewas tentukan perkiraan saat kematian, dari penurunan suhu, lebam mayat, kaku mayat dan perubahan post mortal lainnya; perkiraan saat kematian berkaitan dengan alibi dari para tersangka,

3. Tentukan identitas atau jati diri dari korban, baik secara visual, pakaian, perhiasan, dokumen, medis dan dari gigi; pemeriksaan serologi, sidik jari dan ekslusi di lakukan di laboratorium, jati diri korban dibutuhkan untuk memulai penyidikan, oleh karenabiasanya ada korelasi antara korban dan pelaku, pelaku umumnya telah mengenal siapa korban,

4. Tentukan jenis luka dan jenis kekerasan serta perkiraan sebab kematiannya, jenis luka dan jenis kekerasan dapat memberi informasi perihal alat atau senjata yang dipakaiserta perkiraan proses terjadinya kejahatan tersebut, hal mkana berguna dalam interograsi dan rekonstruksi; dengan diketahui jenis senjata, pihak penyidik dapat melakukan pencarian secara lebih terarah.

5. Buat sketsa keaadaan di TKP secara sederhana dan dapat memberi gambaran posisi korban dikaitan dengan situasi terdapat di TKP,

6. Cari dan kumpulkan benda-benda bukti yang ada kaitannya dengan korban ( sampel biologis ), guna pemeriksaan di laboratorium,

7. Bila terdapat genangan atau bercakbercak darah, lakukan penafsiran dan buat penafsirannya,

8. Bila manghadapi kasus yang berkaitan dengan kejahatan seksual yang diikuti dengan penganiayaan atau pembunuhan, pemeriksaan ditunjukan untuk mencari bercak air mani yang tertinggal di TKP.

Tempat kejadian dinyatakan tertutup oleh karena mungkin sewaktu-waktu masih diperlukan bahan bukti lain. ${ }^{9}$

\section{METODE PENCARIAN BARANG BUKTI}

Untuk meperoleh barang bukti yang diperlukan didalam proses penyidikan 
dikenal 5 macam metode, yaitu: strip method, double strip or grid method, spiral method, zone method dan wheel method: Cara atau metode tersebut tentu sudah diketahui oleh penyidik dan perlu pula diketahui oleh dokter yang melakukan pemeriksaan di TKP agar tidak merubah/ merusak keaslian keadaan TKP. ${ }^{8}$

\section{METODE PENELITIAN}

Desain penelitian ini bersifat deskriptif analitik dengan menggunakan kuesioner sebagai data primer. Kuesioner dijalankan di Polres kota Manado yang diisi oleh para anggota penyidik di polres kota Manado

\section{HASIL PENELITIAN DAN BAHASAN}

Pada penelitian ini total sampel yang digunakan adalah sebanyak 55 sampel. Sampel yang digunakan ialah kuesioner yang diberikan kepada para penyidik di kota Manado dan dijalankan di Polres kota Manado.

Tabel 1: Tabulasi hasil kuesioner

Hasil kuesioner

\begin{tabular}{ccc}
\hline Pertanyaan & Menjawab & $\begin{array}{c}\text { Tidak } \\
\text { Menjawab }\end{array}$ \\
\hline $\mathbf{1}$ & 54 & 1 \\
$\mathbf{2}$ & 55 & 0 \\
$\mathbf{3}$ & 54 & 1 \\
$\mathbf{4}$ & 54 & 1 \\
$\mathbf{5}$ & 49 & 6 \\
$\mathbf{6}$ & 55 & 0 \\
$\mathbf{7}$ & 48 & 7 \\
$\mathbf{8}$ & 51 & 4 \\
$\mathbf{9}$ & 51 & 4 \\
$\mathbf{1 0}$ & 43 & 12 \\
$\mathbf{1 1}$ & 51 & 4 \\
$\mathbf{1 2}$ & 50 & 5 \\
$\mathbf{1 3}$ & 51 & 4 \\
$\mathbf{1 4}$ & 51 & 4 \\
\hline
\end{tabular}

Dari data yang didapatkan terlihat bahwa sebanyak 50 orang penyidik mengetahui bahwa mereka dapat memanggil seorang dokter ke tempat kejadian perkara (Gambar 1).
Gambar 1. Apakah saudara tahu bahwa seorang penyidik dapat memanggil seorang dokter ke tempat kejadian perkara

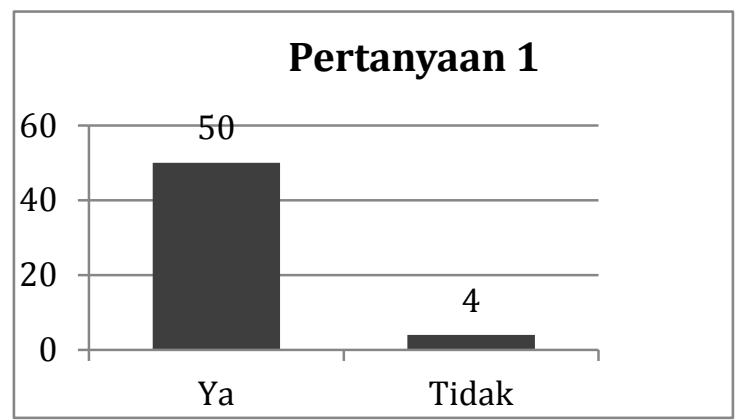

Dari data yang didapatkan melalui kuesioner, terdapat sebesar 49 penyidik yang mengetahui peranan seorang dokter di tempat kejadian perkara (Gambar 2).

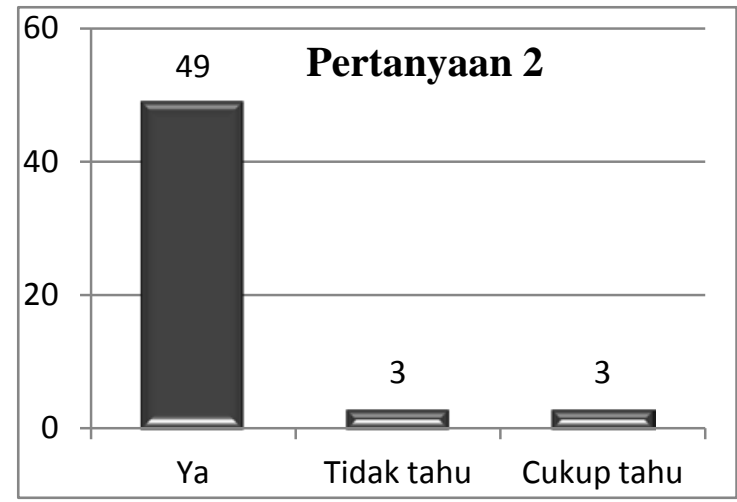

Gambar 2. Apa saudara mengetahui peranan seorang dokter di tempat kejadian perkara

Dari data yang didapatkan dapat dilihat bahwa sebesar 48 penyidik telah mengetahui cara dan prosedur pemanggilan dokter ke tempat kejadian perkara (Gambar 3).

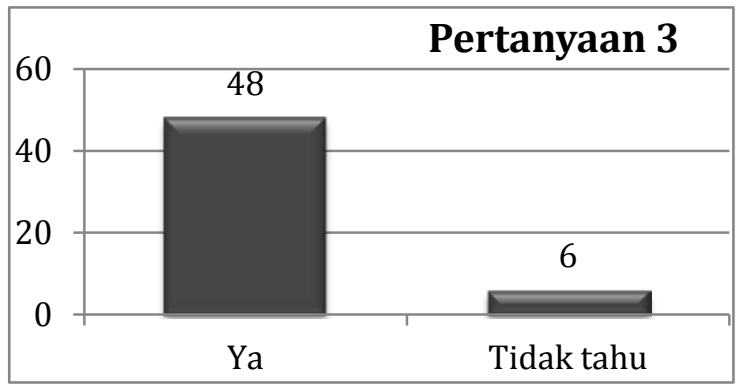

Gambar 3. Apakah saudara mengetahui cara atau prosedur pemanggilan dokter ke tempat kejadian perkara 
Dari data yang didapat sebanyak 44 penyidik menjawab bahwa peranan dokter di tempat kejadian perkara sangat jarang digunakan (Gambar 4).

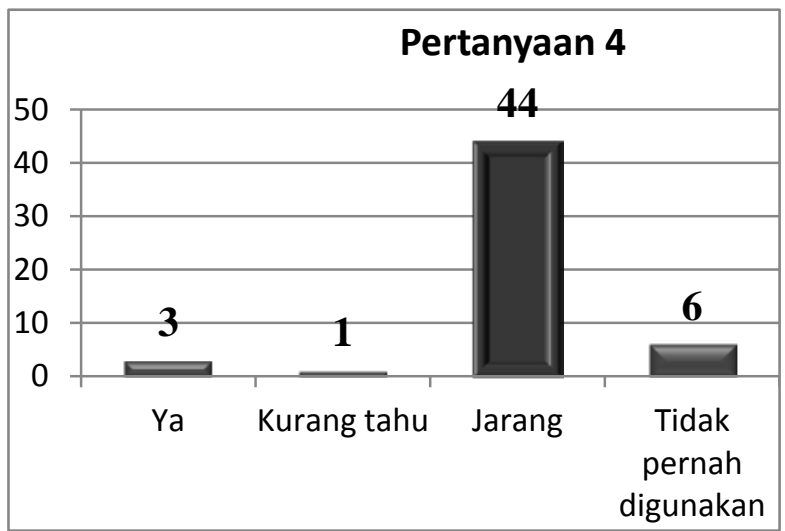

Gambar 4. Apakah peranan dokter di tempat kejadian perkara sudah sering digunakan

Dari data yang didapatkan selain jasa dokter terdapat 20 penyidik yang tidak memerlukan jasa lainnya di tempat kejadian perkara dan 11 orang menjawab fotografer dan psikologi (Gambar 5).

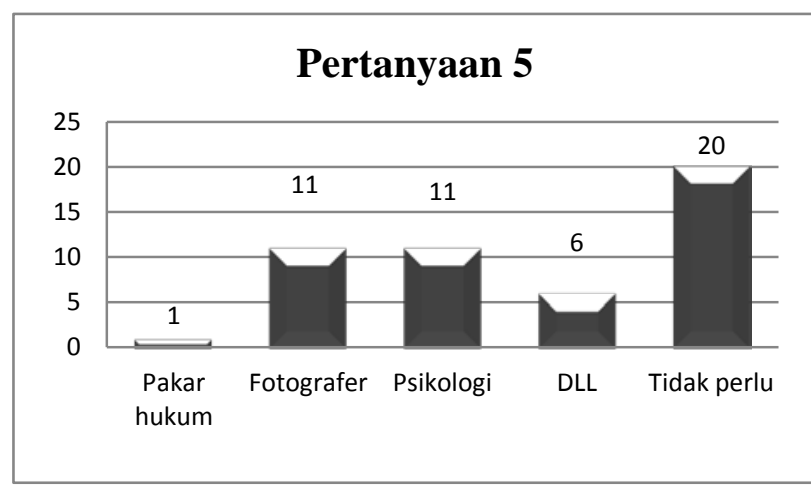

Gambar 5. Selain jasa dokter, apakah ada jasa spesialis lain yang digunakan polisi di tempat kejadian perkara

Bagaimanapun pengetahuan penyidik tentang peranan dokter di tempat kejadian perkara tidak boleh disepelehkan, dan menurut hasil penelitian yang didapatkan dapat terlihat bahwa para penyidik dikota Manado sudah cukup tahu dan sudah berwawasan tinggi tentang peranan dokter di tempat kejadian perkara.

Dari hasil penelitian didapatkan hasil sebanyak 27 penyidik menyatakan bahwa tim yang berada di tempat kejadian perkara sekarang tidaklah cukup, dan dibutuhkan peranan jasa spesialis lainnya (Gambar 6).

\section{Pertanyaan 6}

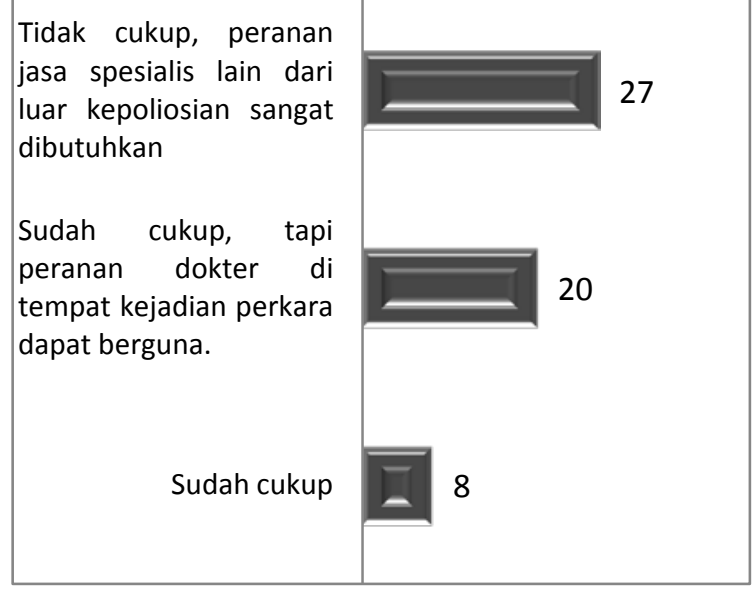

Gambar 6. Menurut anda sendiri apakah tim yang ada di tempat kejadian

Dari hasil yang didapatkan 36 penyidik berharap dapat menggunakan jasa doker tempat kejadian perkara pada kasus-kasus pembunuhan (Gambar 7).

\section{Pertanyaan 7}

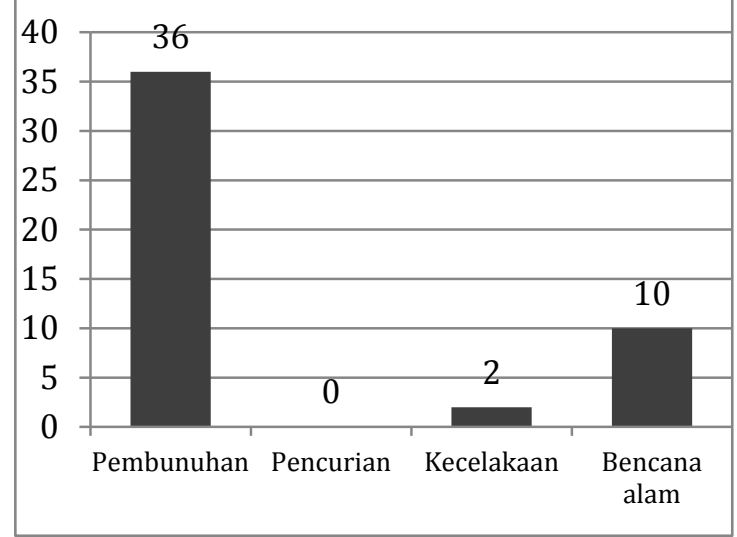

Gambar 7. Pada tempat kejadian perkara seperti apa anda berharap jasa dokter dapat digunakan

Dari data yang didapatkan sebanyak 33 penyidik di kota manado berharap dengan adanya peran seorang dokter di tempat kejadian perkara maka kasus-kasus yang berhubungan dengan medis dapat diselesaikan dengan lebih cepat (Gambar 8). 


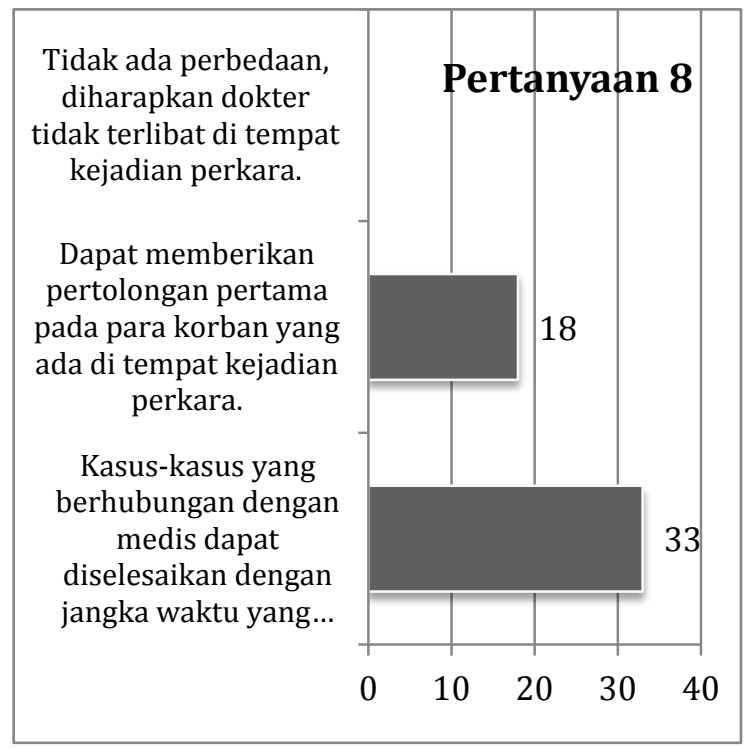

Gambar 8. Perbedaan seperti apa yang anda harapkan terjadi dengan adanya dokter di tempat kejadian perkara

Dari data yang didapatkan melalui hasil kuesioner terlihat bahwa 49 orang penyidik di kota manado berpikir bahwa kerja sama dari luar pihak kepolisian dapat membantu pekerjaan di tempat kejadian perkara (Gambar 9).

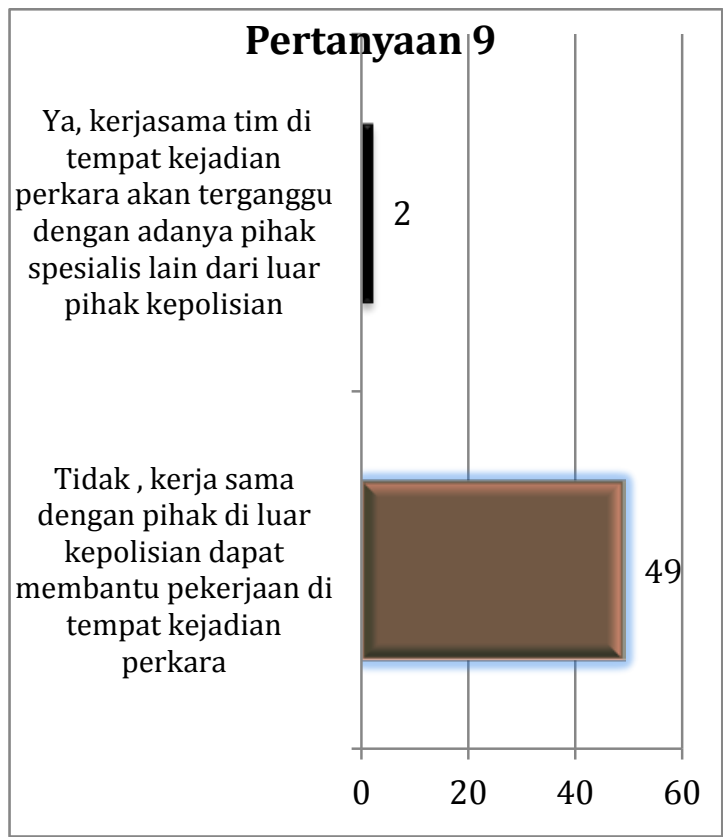

Gambar 9. Apakah anda merasa terganggu dengan adanya pihak spesialis lain selain polisi di tempat kejadian perkara.

Dari pihak penyidik berpendapat bahwa seorang spesialis dari luar pihak kepolisian harus mengikuti persekolahan yang mengajari tentang tempat kejadian perkara (Gambar 10).

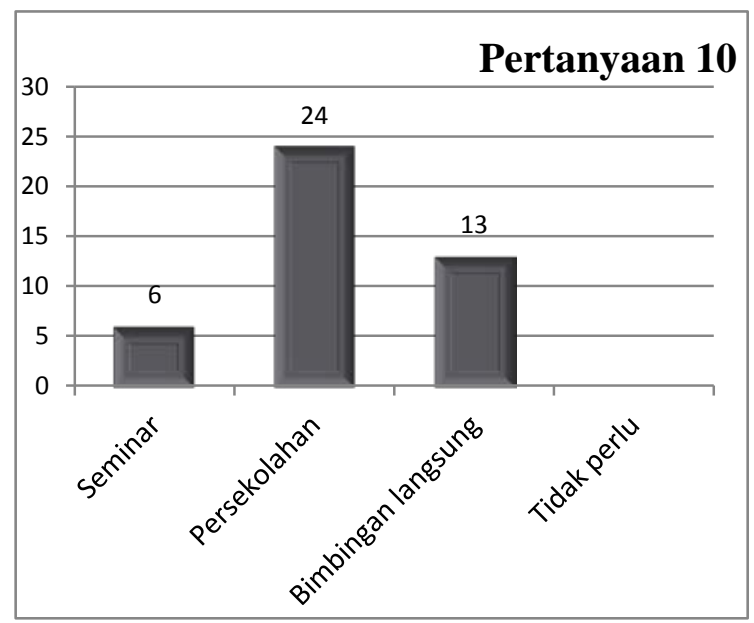

Gambar 10. Menurut anda apakah pihak spesialis dari luar pihak kepolisian termasuk dokter membutuhkan pelatihan khusus untuk dapat masuk ke tempat kejadian perkara.

Penyidik masih membutuhkan jasa bantuan spesialis lain selain dari pihak kepolisian di tempat kejadian perkara dan mau bekerja sama dengan pihak spesialis lainnya secara profesional teatapi sangat direkomendasikan untuk pihak spesialis lainnya untuk mengikuti bimbingan atau panduan terlebih dahulu sebelum memasuki tempat kejadian perkara.

Dari data yang didapatkan semua penyidik berharap bahwa jasa kedokteran dapat dipakai di tempat kejadian perkara untuk kedepannya (Gambar 11)

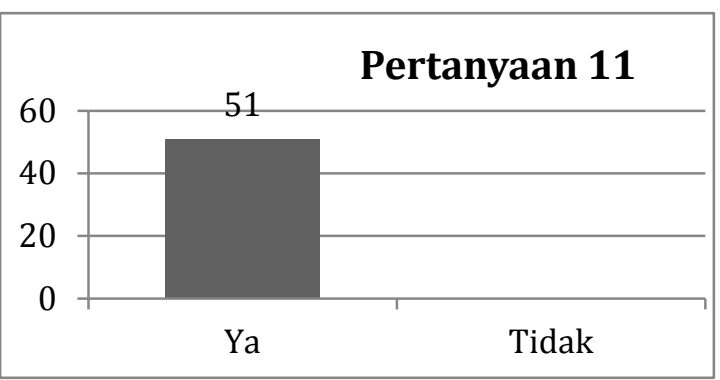

Gambar 11. Untuk kedepannya apakah anda berharap bahwa jasa kedokteran dapat dipakai di tempat kejadian perkara

Dari hasil yang didapat 48 orang penyidik menjawab bahwa mereka berniat untuk mempelajari lebih lanjut tentang 
peranan seorang dokter di tempat kejadian perkara (Gambar 12)

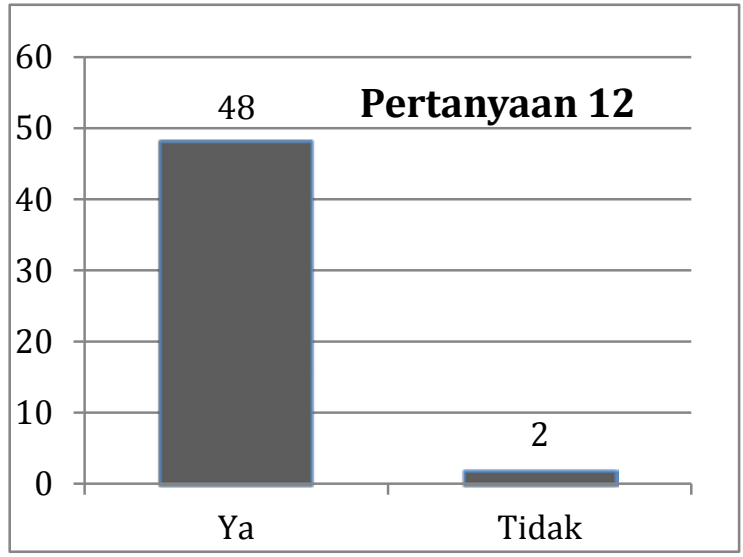

Gambar 12. Apakah anda berniat untuk mempelajari lebih lanjut tentang peranan seorang dokter di tempat kejadian perkara

Terlihat dari hasil penelitian bahwa 42 penyidik memilih untuk menggunakan jasa dokter di kasus-kasus tertentu saja (Gambar 13).

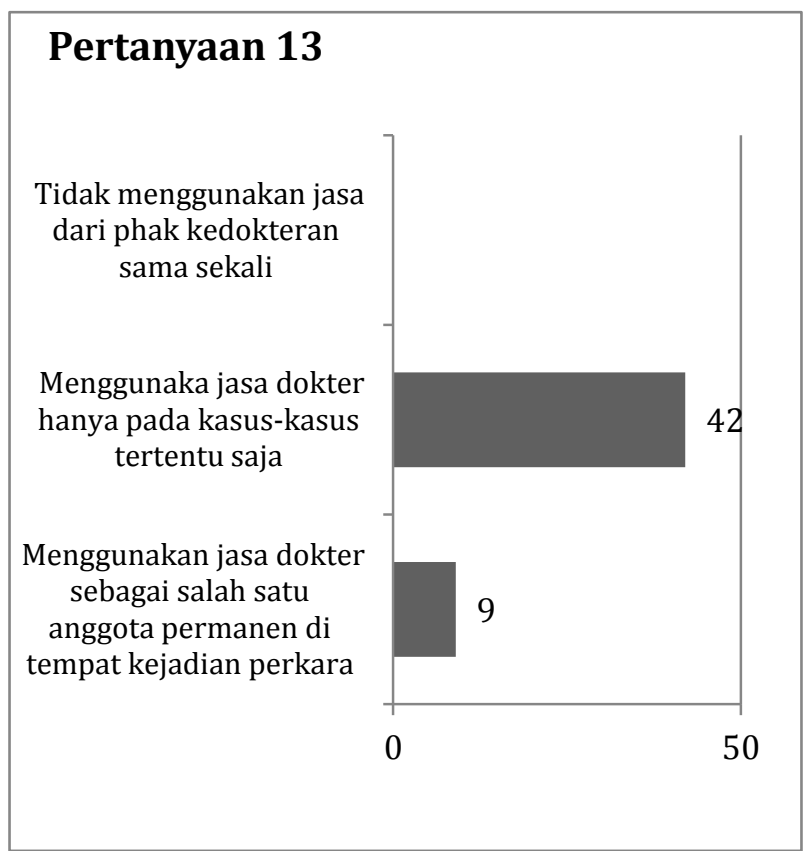

Gambar 13. Jika anda mendapatkan kesempatan untuk menggunakan jasa dokter di tempat kejadian perkara. apakah tindakan yang akan anda lakukan

Dari data yang ada 49 penyidik memilih untuk menghubungi pihak kedokteran jika mereka menemui kasus- kasus yang berhubungan dengan medis (Gambar 14)

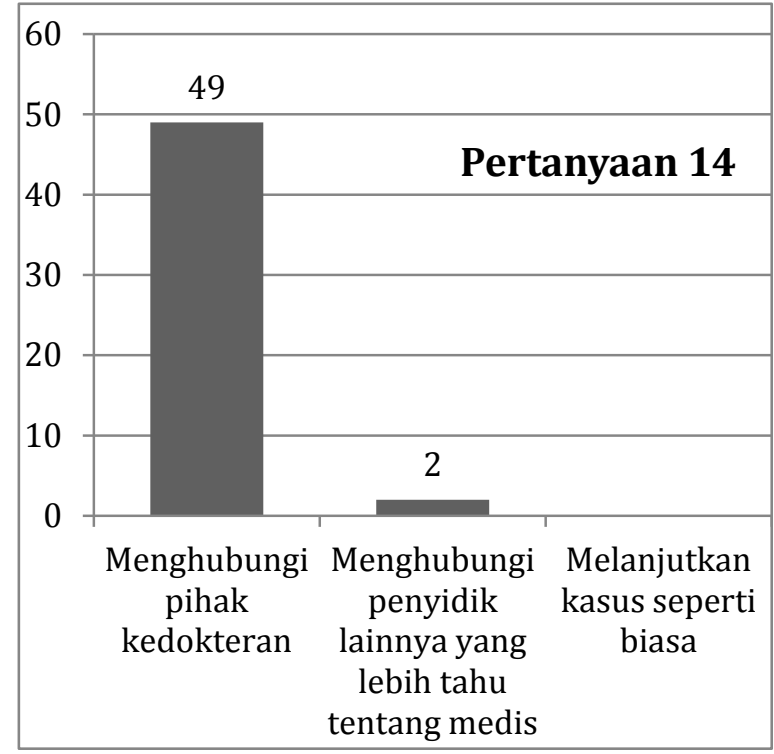

Gambar 14. Tindakan apa yang akan anda lakukan jika suatu saat anda mendapatkan kasus yang berhubungan dengan medis

Dapat dilihat jika kedepannya penyidik sangat berharap dapat bekerja sama dengan pihak kedokteran dalam menyelesaikan kasus-kasus yang berbau medis dan akan sangat tertolong dengan adanya pihak kedokteran di tempat kejadian perkara.

\section{SIMPULAN}

Dari semua data diatas dapat disimpulkan secara umum bahwa peran dokter di tempat kejadian perkara sangatlah penting, dan dengan adanya bantuan dari pihak kedokteran maka para penyidik dapat merasa lebih baik dalam menangani kasuskasus yang berbau medis.

\section{SARAN}

Sebaiknya seorang dokter dapat mengetahui peranannya di tempat kejadian perkara dan mencari tahu lebih lanjut tentang proses investigasi di tempat kejadian perkara

\section{DAFTAR PUSTAKA}

1. Dorland, WA Newman. Kamus kedokteran Dorland. Jakarta: penerbit buku kedokteran EGC, 2006. 
2. Budiyanto, Arif, et al. Ilmu Kedokteran Forensik. Jakarta: Universitas Indonesia, 1997.

3. Magister Teknik Informatika UII. Anis: Pengertian Forensik dan Kriminalistik [Anis's Blog]. Nodate [cited 2014 des 15]. Avaiable from: https://anissusilaabadi.wordpress.com/p engertian-forensik-dan-kriminalistik/

4. Darmabrata W, Nurhidayat AW, Psikiatri Forensik. Jakarta: Penerbit Buku Kedokteran EGC, 2003.

5. Idries AM, Budiningsih Y, Mallo JF, Atmadja DS, Dundu AE, Kristanto E, et al. Pedoman Praktis Ilmu Kedokteran Forensik Bagi Praktisi
Hukum. Jakarta: Sagung Seto; 2009.

6. Idries AM. Penerapan Ilmu Kedokteran Forensik dalam Proses Penyidikan. Jakarta: CV. Sagung Seto, 2008.

7. Dirgantara, Andi M. Peranan polisi sebagai penyidik dalam mencari bukti pada proses penangannan TKP. Medan: Fakultas Hukum Universitas Sumatera Utara, 2011.

8. Idries AM. Pedoman Ilmu Kedokteran Forensik. Jakarta Barat: Binarupa Aksara, 1997.

9. Abdulassalam HR, Desasfuyanto. Buku Pintar Forensik (pembuktian ilmiah). Jakarta: PTIK press Jakarta, 2014. 